\title{
Analisis Perbandingan Model Altman, Grover, Zmijewski Dan Springate Sebagai Prediksi Financial Distress
}

\author{
Enggar Prasetianingtias ${ }^{1}$, Dewi Kusumowati ${ }^{2}$ \\ 1 Universitas Merdeka Malang, Jl. Terusan Raya Dieng 62-64, Malang, 5146, Indonesia \\ 2 Universitas Merdeka Malang, Jl. Terusan Raya Dieng 62-64, Malang, 5146, Indonesia
}

\begin{abstract}
This study aims to compare the accuracy of Altman, Grover, Zmijewski and Springate models to predict financial distress. Comparison has done by analyzing the level of accuracy of each model. The variables in this study are the financial ratios of Altman, Grover, Zmijewski, and Springate towards accuracy in predicting Financial Distress. The sample used is an agriculture company listed on the IDX during 2016-2017. The sampling technique was purposive sampling with a total sample of 34 companies. The criteria in purposive sampling are companies that publish annual financial statements in the period 2016-2017 and stock price data are available on the trading date ending in the year. The results show that the Grover G-Score model is a prediction model with a highest accuracy of $85.29 \%$ by comparing it with actual conditions. Grover model is also the most accurate to predict financial distress on Negative Net Income and dividend payment of $85 \%$ accuracy.
\end{abstract}

Keywords: Altman; Grover; Zmijewski; Springate Model; Financial Distress

\section{PENDAHULUAN}

Pada umumnya perusahaan go public memanfaatkan keadaaan pasar modal sebagai sarana untuk mendapatkan sumber dana atau alternatif pembiayaan. Dengan kondisi perekonomian yang tidak menentu mengakibatkan tingginya resiko perusahaan dalam mengalami kesulitan keuangan. Hal ini akan berpengaruh bagi kelanjutan operasi perusahaan, oleh karena itu, pentingnya model prediksi financial distress dalam menganalisis suatu perusahaan. Prediksi financial distress sangat dibutuhkan oleh berbagai pihak seperti debitur, investor, auditor, pemerintah, akuntan dan manajemen.

Financial distress merupakan kondisi dimana perusahaan tidak mampu lagi dalam melunasi kewajiban jangka pendeknya. Dalam hal ini terjadinya financial distress pada umumnya bisa disebabkan dari pihak internal maupun eksternal. Masalah internal biasanya timbul karena manajemen kurang teliti dalam mengambil sebuah kebijakan, sehingga banyak masalah keuangan yang timbul.

Kebutuhan mengenai prediksi dan analisis kondisi financial distress sangat penting tidak hanya bagi investor dan kreditor, tetapi bai perusahaan itu sendiri. Financial distress biasanya digunakan sebagai evaluasi kinera perusahaan pada periode tertentu. Sehingga banyak model prediksi yang dikembangkan dalam menganalisis financial distress pada suatu perusahaan. Salah satu model prediksi yang banyak digunakan saat ini adalah model Altman, yang merupakan rasio-rasio keuangan yang menggambarkan suatu hubungan atau pertimbangan antara suatu jumlah tertentu dengan jumlah yang lain. Rasio dapat menjelaskan atau memberi gambaran kepada penganalisis tentang baik dan buruknya keadaan atau posisi keuangan suatu perusahaan suatu perusahaan terutama angka rasio pembanding yang digunakan sebagai standar.

Tekanan keuangan atau financial distress adalah kejadian yang mengawali kebangkrutan dalam sebuah perusahaan. Model financial distress perlu dikembangkan, karena dengan mengetahui kondisi sejak awal, perusahaan diharapkan dapat melakukan tindakan antisipasi. Minimal untuk memperkecil potensi kebangkrutan. Beberapa model dalam memprediksi financial distress yaitu model Altman, model Zmijewski, model Grover, model Ohlson, model Fulmer dan sebagainya. Dengan mengetahui modelmodel prediksi kondisi keuangan yang tepat dan menggunakan informasi keuangan perusahaanperusahaan yang terpublikasi di bursa efek indonesia, diharapkan investor maupun pihak-pihak lain yang berkepentingan dalam menganalisis keuangan dapat menggambil keputusan yang tepat. 
Terdapat beberapa penelitian menggenai ketepatan dalam menganalisis financial distress yang telah dilakukan sebelumnya, diantaranya Primasari (2017) dengan menggunakan empat metode analisis financial distress. Yakni Altman, Grover, Springate dan Zmijewski pada sub sektor customer good menunjukan bahwa metode Altman z-score sebagai model prediksi financial distress paling akurat dibandingkan dengan ketiga model lainnya. Penelitian ini merupakan replikasi dari Primasari (2017) akan tetapi perbedaaannya pada sampel yaitu sub sektor agriculture yang terdaftar di bursa efek indonesia. Sektor agriculture pada tahun 2018 mempunyai dua emiten serta tidak ada perusahaan agriculture yang delisting selama lima tahun terakhir.

\section{METODE}

Penelitian ini merupakan penelitian deskriptif kuantitatif dengan jenis data kuantitatif dengan sumber data sekunder yang berasal dari website berupa laporan keuangan.Teknik pengumpulan datadengan menggunakan dokumentasi. Variabel dalam penelitian ini adalah financial distress. Financial distress merupakan tahap penurunan kondisi keuangan perusahaan sebelum terjadinya likuidasi (Widarjo dan Setiawan, 2009). Financial distress diukur dengan variabel dummy, 1 = perusahaan menggalami financial distress; $0=$ perusahaan sehat. Financial distress digunakan sebagai peringatan dini bagi perusahaan dalam menggelola perusahaan tersebut. Hasil model prediksi yang digunakan akan dibandingkan dengan kondisi yang sebenarnya. Dengan kriteria Negative Net Income dan Devident Paymnet.

Analisis data dalam penelitian ini adalah deskriptif kuantitatif yang melalui tahapan sebagai berikut: 1)Menghitung 9 rasio keuangan, 2) Menghitung indeks financial distress dari setiap model prediksi yang digunakan, 3) Mengelompokan hasil indeks financial distress tersebut berdasarkan hasil kriteria kondisi keuangan perusahaan. Dalam penelitian ini perusahaan yang masuk dalam grey area akan dikategorikan kedalam perusahaan yang tidak menggalami kondisi financial distress, 4) Membandingkan hasil perhitungan indeks financial distress tersebut dengan kondisi keuangan sebenarnya, yang mengacu pada 2 kondisi yaitu laba bersih negatif selama dua tahun dan perusahaan tidak membagi deviden, 5) Selanjutnya dari hasil analisis perbandingan tersebut, akan dihitung persentase keakuratan untuk masing-masing model prediksi. Tingkat akurasi menunjukan berapa persen model prediksi ynag benar dari keseluruhan sampel yang ada. Tingkat akurasi tiap model dihitung dengan cara sebagai berikut:

Tingkat akurasi $=$ (jumlah sampel yang hasil prediksi sama dengan kondisi sebenarnya / jumlah sampel) x 100\%. 6) Menarik kesimpulan, dari keempat model prediksi yang mempunyai persentase keakuratan paling tinggi.

\section{HASIL}

\section{Perhitungan Model-model Prediksi Kebangkrutan}

Berikut adalah hasil perhitungan perbandingan persentase model prediksi fianancial distress untuk masing-masing model:

Tabel 1: Perbandingan Hasil Persentase Model Prediksi Financial Distress

\begin{tabular}{|c|l|c|c|c|c|c|}
\hline \multirow{2}{*}{ No } & \multirow{2}{*}{ KETERANGAN } & \multicolumn{4}{|c|}{ TAHUN 2016 - 2017 } & \multirow{2}{*}{ Rata-rata } \\
\cline { 3 - 6 } & & ALTMAN & GROVER & ZMIJEWSKI & SPRINGATE & \\
\hline 1 & Financial Distress & $53 \%$ & $35 \%$ & $97 \%$ & $41 \%$ & $56.62 \%$ \\
\hline 2 & Sehat & $47 \%$ & $65 \%$ & $3 \%$ & $59 \%$ & $43.38 \%$ \\
\hline
\end{tabular}

Sumber : Data diolah, 2019

Dapat dilihat dari perhitungan diatas bahwa tingkat financial distress yang tertinggi pada perusahaan agriculture adalah model prediksi Zmijewski. Persentase prediksi financial distress yang yang ditunjukan pada model Zmijewski ini lebih tinggi dari model-model yang lain, yakni sebesar 97\%. Sebaliknya dalam 
kategori sehat dengan persentase sebesar 3\%. Selanjutnya model Altman sebesar 53\%, model Springate sebesar $41 \%$ dan yang terakhir model Grover sebesar 35\%. Financial distress ditandai dengan kecenderungan memiliki beberapa rasio keuangan negatif yang tinggi, berarti tidak adanya kesesuaian perbandingan masing-masing rasio.

Rata-rata persentase prediksi financial distress menunjukan bahwa perusahaan agriculture yang termasuk dalam kategori financial distress sebesar $56.62 \%$ dari pada perusahaan dalam keadaan sehat $43.38 \%$. Perusahaan financial distress. karena menurut perhitungan rata-rata perusahaan dalam kategori sehat mempunyai persentase sebesar $43.38 \%$. Dengan demikian beberapa perusahaan sektor agriculture akan mengalami financial distress jika manajemen tidak tepat dalam mengatur kebijakan keuangan dengan tepat.

Perbandingan model prediksi dengan kondisi sebenarnya

Berikut adalah hasil perhitungan tingkat keakurasian masing-msing model prediksi financial distress:

Tabel 2: Tingkat Keakurasian Financial Distress

\begin{tabular}{|l|c|c|c|c|c|}
\hline \multirow{2}{*}{ Model Prediksi } & \multirow{2}{*}{$\mathrm{N}$} & \multicolumn{2}{|c|}{ Tingkat Akurasi Rill Berdasarkan } & \multirow{2}{*}{ Rata-rata } & \multirow{2}{*}{ Peringkat } \\
\cline { 3 - 5 } & & Net Income Negatif & Deviden Payment & & \\
\hline ALTMAN Z-SCORE & 34 & $68 \%$ & $68 \%$ & $67.65 \%$ & 3 \\
\hline GROVER G-SCORE & 34 & $85 \%$ & $85 \%$ & $85.29 \%$ & 1 \\
\hline ZMIJEWSKI X-SCORE & 34 & $15 \%$ & $35 \%$ & $25.00 \%$ & 4 \\
\hline SPRINGATE S-SCORE & 34 & $76 \%$ & $91 \%$ & $83.82 \%$ & 2 \\
\hline
\end{tabular}

Sumber : Data diolah, 2019

\section{PEMBAHASAN}

Dari hasil perbandingan tingkat akurasi model prediksi kondisi financial distress, dapat disimpulkan bahwa model Grover G-Score memiliki tingkat akurasi tertinggi dibandingkan dengan model-model yang lain, yakni sebesar $85.29 \%$. Hal ini dikarenakan model Grover memiliki tingkat tertinggi dalam memprediksi Negative Net Income dan devident payment sebesar $85 \%$. Selanjutya disusul dengan model Springate dengan persentase sebesar $83.82 \%$, model Altman dengan persentase sebesar $68.65 \%$ dan yang terakhir dengan Zmijewski dengan persentase sebesar 25\%.

Hal ini didukung dengan penelitian Primasari (2017) pada perusahaan industri barang-barang kosumsi yang menyatakan bahwa model Grover merupakan model terbaik dalam memprediksi financial distres. Model Grover dapat digunakan para manajer keuangan untuk melakukan evaluasi kinerja perusahaan. meskipun keempat model tersebut menggunakan rasio-rasio yang hampir sama dan modelmdel tersebut sering digunakan untuk memprediksi financial distress, tetapi penelitian ini membuktikan bahwa perhitungan keempat model.

Model Grover terdapat ROA. Return On Asset merupakan rasio yang menggukur laba bersih tahun yang didapat dari pemakaian aktiva. ROA yang semakin tinggi menunjukan profitasbilitas perusahaan yang membaik. Selanjutnya dengan persentase sebesar $83.82 \%$ keakuratan model Springate dalam memprediski financial distress dengan kondisi sebenarnya. Hal ini sesuai dengan penelitian yang dilakukan oleh Rifqi (2009) yang menyatakan bahwa model Springate merupakan model terbaik untuk memprediksi financial distress pada perusahaan manufaktur. Model Springate memiliki 1 rasio yang berbeda yaitu Retained Earning to Total Assets yang digunakan untuk menggukur profitabilitas perusahaan. rasio ini digunakan untuk melihat kinerja manajemen dalam satu periode akuntansi dari model Springate Rasio ini semakin besar maka profitabilitas perusahaan tersebut semakin baik disetiap periodenya.

Model Altman Dengan persentase sebesar $68.65 \%$ keakuratan dalam memprediski financial distress dengan kondisi sebenarnya. Hal ini sesuai dengan penelitian yang dilakukan oleh Hadi dan Anggraeni (2008) yang menyatakan bahwa model Altman merupakan model terbaik untuk memprediksi financial 
distress pada perusahaan delisting kecuali delisting bank. Model Altman memiliki rasio book value of equity to book value of debt. Rasio ini yang membedakan model altman dengan model prediksi lainnya. Ekuitas diukur dengan nilai pasar gabungan dari semua saham, sementara total kewajiban terdiri dari kewajiban lancar dan kewajiban jangka panjangnya. Altman menjelaskan bahwa rasio ini menunjukan besar aset perusahaan yang dapat menurun nilainya (diukur dengan nilai pasar ekuitas ditambah kewajiban) sebelum kewajiban melebihi aset dan perusahaan mengalami financial distress.

Model Zmijewski memakai rasio-rasio yang sangat berbeda dengan model yang lain. Dengan persentase $25 \%$ keakuratan dalam meprediksi financial distress dengan kondisi yang sebenarnya. Hal ini bertentangan dengan penelitian yang pernah dilakukan oleh Risawati (2012) yang menyatakan bahwa model Zmijewski merupakan model yang paling sesuai ditetapkan untuk perusahaan manufaktur. Rasio yang digunakan model Zmijewski yaitu ROA, Current Ratio, dan Debt to Aset Ratio. ROA menunjukan jumlah laba bersih yang dihasilkan dari produktivitas asetnya. Current ratio merupakan rasio yang digunakan untuk menggukur kemampuan perusahaan dalam membayar kewajiban jangka pendeknya dengan menggunakan aset lancar yang dimiliki. Debt to Asset Ratio merupakan sebuah rasio untuk menggukur jumlah aset yang dibiayai oleh kewajiban.

Satu hal yang perlu diingat adalah hasil model ini hanya memprediksi financial distress bukan Operasional distress atau likuidasi. Selain itu, setiap model yang diciptakan tidak pernah sempurna. Maka dari itu, hasil prediksi ini tidak boleh dianggap sebagai absolut. Hasil prediksi hanya sebatas indikator supaya investor / kreditur lebih berhati-hati atas perusahaan-perusahaan yang mengalami financial distress dan menggali informasi tambahan mengenai perusahaan

\section{SIMPULAN DAN SARAN}

Berdasarkan hasil penelitian dan pembahasan pada penelitian ini, maka dapat disimpulkan model Altman, model Grover, model Zmijewski dan model Springate dapat digunakan sebagai prediksi financial distress terhadap perusahaan agriculture. Model Altman S-score dapat digunakan untuk memprediksi financial distress pada perusahaan Agriculture. Dengan persentase prediksi sebesar 53\% yang terdiri dari 18 perusahaan mengalami financial distress. Dari persentase prediksi tersebut, dibuat perbandingan dengan kategori Negative net income dan devident payment diperoleh tingkat keakuratan sebesar $67.65 \%$.

Model Grover G-score dapat digunakan untuk memprediksi financial distress pada perusahaan Agriculture, dengan persentase prediksi sebesar 35\% yang terdiri dari 12 perusahaan yang menggalami financial distress. hasil persentase tersebut dilakukan perbandingan dengan kategori Negative net income dan devident payment. Hasil dari perbandingan tersebut diperoleh tingkat keakuratan sebesar $85.29 \%$.

Model Zmijewski $X$-score dapat digunakan untuk memprediksi financial distress pada perusahaan Agriculture, dengan persentase prediksi sebesar 97\% terdiri dari 33 perusahaan yang mengalami financial distress. Dari hasil tersebut dibandingkan kondisi sebenarnya yakni Negative Net Income dan Devident Payment. Dari hasil tersebut dapat ditemukan keakuratan model Zmijewski dalam memprediksi financial distress dengan kondisi yang sebenarnya sebesar $25 \%$.

Model Springate S-score dapat digunakan untuk memprediksi financial distress pada perusahaan Agriculture, dengan persentase prediksin sebesar 41\% yang terdiri dari 14 perusahaan menggalami financial distress. hasil dari persentase tersebut akan dibandingkan dengan kondisi yang sebenarnya dengan kategori Negative net income dan devident payment. Dari hasil perbandingan tersebut dapat ditemukan keakuratan model prediksi Springate dengan konsisi sebenarnya sebesar $83.82 \%$.

Perbandingan dari keempat model prediksi financial distress, yaitu Altman, Grover, Zmijewski dan Springate diketahui bahwa model Grover merupakan model terbaik dalam memprediksi financial distress pada perusahaan Agriculture. Hal ini ditunjukan pada tingkat keakurasian model Grover paling tinggi dibandingkan dengan model Altman, Zmijewski dan Springate sebesar 85.29\%. Hal ini menunjukan bahwa model Grover merupakan model prediksi yang paling akurat dalam memprediksi financial distress. Hal ini dikarenakan model Grover memiliki perhitungan yang didasarkan pada satu komponen rasio likuiditas (WCTA) dan dua rasio Profitabilitas (EBITTA dan ROA). Pada rasio likuiditas (WCTA) digunakan untuk melihat kemampuan perusahaan dalam memenuhi hutang jangka pendeknya yang terkait dengan modal 
kerja dijamin oleh total aset perusahaan. Hal ini ditunjukan pada perusahaan yang menggalami financial distress dalam memenuhi jangka pendeknya sangat rendah. Sehingga kemampuan perusahaan dalam memenuhi kewajiban jangka pendeknya kurang efektif, serta akan berpengaruh juga pada profitabilitasnya.

\section{DAFTAR PUSTAKA}

Aprilia, Ajeng Eka. (2018). Analisis Perbandingan Altman Z-score, Zmijewski dan Springate dalam Memprediksi Kebangkrutan Perusahaan Delisting Di BEI. Skripsi Universitas Muhammadiyah Surakarta.

Balafif, Aryanti, T dan Shirin. (2007).Analisis Faktor yang Mempengaruhi Tingkat Kesehatan Bank dan Regresi Logit. Journal The Winners, 8(2):111-125.

Cahyoningrum, N dan A. M. Haryanto. (2012). Analisis Manfaat Rasio Keuangan Dalam Memprediksi Pertumbuhan Laba (Studi Kasus Perusahaan Manufaktur Yang Terdaftar di Bursa Efek Indonesia Periode 2005- 2010). Disertasi Doktoral Universitas Dipponegoro.

Darsono. (2008). Pedoman Praktis Memahami Laporan Keuangan. Penerbit ANDI. Yoyakarta.

Devi, Komang dan Merkusiwati. (2014). Analisis Komparasi Potensi Kebangkrutan Dengan Metode ZScore Altman, Springate, dan Zmijewski Pada Industri Kosmetik yang Terdaftar di Bursa Efek Indonesia. E-Jurnal Akuntansi Universitas Udayana Vol 7 No 1.

Eidleman, G. (1995). Z-scores - A Guide to Failure Prediction. The CPA Journal Online. Vol 65 No 2.

Fatmawati, Mila. (2012). Penggunaan Metode The Zmijewski Model, The Altman Model dan The Springate Model Sebagai Prediktor Delisting. Jurnal Keuangan dan Perbankan, vol 16 no 1, 56-65.

Gunawan et al. (2017). Perbandingan Prediksi Financial distress dengan Model Altman, Grover,dan Zmijewski. Jurnal Akuntansi dan Investasi, vol 18 no 1, 119-127.

Hapsari, Indry, E. (2012). Kekuatan Rasio Keuangan dalam Memprediksi Kondisi Financial distress Perusahaan Manufaktur di BEI. Jurnal Dinamika Manajemen, 101-109

Hardiningtyas, Amilia, L dan Winny. (2005). Analisis Rasio Camel Terhadap Prediksi Kondisi Bermasalah Pada Lembaga Perbankan Periode 2000-2002. Jurnal Akuntansi dan Keuangan,7(2): 131-147.

Ikatan Akuntan Indonesia (IAI). (2009). Standar Akuntansi Keuangan Entitas Tanpa Akuntabilitas Publik (SAK ETAP). Dewan Standar Akuntansi Keuangan Ikatan Akuntan Indonesia. Jakarta.

Indirianto, Nur dan Supomo. (2002). Metodologi penelitian Bisnis Untuk Akuntansi dan Manajemen. Edisi Pertama. BPFE. Yogyakarta.

James dan Moira. (2005). Memahami Laporan Keuangan (mamanfaatkan Informasi Keuangan Untuk Pengendalian Bisnis Anda).Cetakan ketiga.PPM. Jakarta.

Kasmir. (2014). Dasar-dasar Perbankan.Edisi Revisi 2008. PT Raja Grafindo Persada. Jakarta.

Kieso, Donald E, Jerry J. Weygandt, dan Terry D. Warfield. (2007). Akuntansi Intermediete, Terjemahan Emil Salim. Jilid I. Edisi kesepuluh. Penerbit Erlangga. Jakarta

Kurniawati, Lintang dan Nur Kholis. (2016). Analisis Prediksi Financial Distress Pada Perusahaan Perbankan Syariah Di Indonesia. Menakar Peran Profesi sebagai Engine of Reform Dalam Pembangunan Global Berkelanjutan.

Luciana. (2006). Prediksi Kondisi Financial distress Perusahaan Go Public Dengan Menggunakan Analisis Multinominal Logit. Jurnal Ekonomi dan Bisnis , 7(3), 183-210.

Meilawati, Anggi. (2016). Analisis Perbandingan Model Springate dan Altman Z-score Terhadap Potensi Financial distress. Jurnal Akuntansi dan Pendidikan, vol 5 no 1.

Munawir. (2007). Analisis Laporan Keuangan. Liberty. Yogyakarta.

Oktaviandri, Annisa, Anisah Firli, dan Aldilla Irandianty. (2015). Analisis Prediksi kebangkrutan dengan Model Altman, Springate, Ohlson dan Grover Pada Perusahaan Di Sektor Pertanian BEI 2011-2015. Majalah Ilmiah Unikom, Vol.15 (No. 1). 
Pambekti, Galuh Tri. (2014). Analisis Ketepatan Model Altman, Springate, Zmijewski, dan Grover Untuk Memprediksi Financial distress (Studi Pada Perusahaan yang Masuk Dalam Daftar Efek Syariah Tahun 2009-2012). Disertasi Doktoral Universitas Islam Negeri Sunan Kalijaga.

Platt dan Platt. (2006). Understanding Differences Between Financial distress and Bankruptcy. Review of Applied Economics, vol 2 no 2.

Rifqi, Muhammad. (2009). Analisis Perbandingan Model Prediksi Financial distress Altman, Ohlson, Zmijewski dan Springate dalam Penerapannya Di Indonesia. Skripsi Universitas Indonesia.

Rismawaty,. (2012). Analsis Perbandingan Model Prediksi Financial distress Altman, Springate, Ohlson, dan Zmijewski (Studi Emperis Pada Perusahaan Food and Beverage yang Terdaftar di Bursa Efek Indonesia). Skripsi

Ryan dan Miyosi. (2009). Membuat Laporan Keuangan Gampang. Dunia Cerdas. Jakarta.

Santoso, Singgih. (2010). Statistik Parametik, Konsep dan Aplikasi dengan SPSS. Cetakan Pertama. PT Elex Media Koputindo. Jakarta

Sari, Enny Wahyu Puspita. (2015). Penggunaan Model Zmijewski, Springate, Altman Z-Score, dan Grover dalam Memprediksi Kepailitan Pada Perusahaan Transportasi yang Terdaftar Di Bursa Efek Indonesia. Skripsi Universitas Dian Nuswantoro Semarang.

Sari, Maria dan Prihanthini. (2013). Prediksi Kebangkrutan Dengan Model Grover, Altman Z-Score, Springate,dan Zmijewski pada Perusahaan Food and Beverage Di Indonesia. E-Jurnal Akuntansi Universitas Udayana, 5(2): 417-435.

Sari, Ratna Candra dan Zurohtun. (2006). Keinformatifan Laba di Pasar Obligasi dan Saham. Uji Liquidation Opinion Hypotesis, Simposium Nasional Akuntansi 9 Padang.

Subramanyam, K. R. (2012). Analisis Laporan keuangan: Financial distress statment. Edisi. Cetakan Pertama. Salemba Empat. Jakarta.

Susanti, Neneng. (2016). Analisis Kebangkrutan Dengan Menggunakan Metode Altman Z-score, Springate, dan Zmijewski Pada Perusahaan Semen Yang terdaftar di BEI Periode 2011-2015. Jurnal Aplikasi Manajemen, vol 14 no 4.

Tania, May dan Edi. (2018). Ketepatan Model Altman, Zmijewski, dan Grover Dalam Memprediksi Financial Distress. Jurnal Review Akuntansi dan Keuangan, Vol 8, No 1.

Widarjo, W dan D, Setiawan. (2009). Pengaruh Rasio Keuangan Terhadap Kondisi Financial distress Perusahaan Otomotif. Jurnal Bisnis dan Akuntansi, Vol 11 no 2.

Wilopo, Prediksi Kebangkrutan Bank. (2001). Jurnal Riset Akuntansi Indonesia, 4(2):184-198

Wulandari et al. (2014). Analisis Perbandingan Model Altman, Springate, Ohlson, Fulmer, CA-Sore dan Zmijewski dalam Memprediksi Financial distress (Studi Emperis Pada Perusahaan Food And Beverage yang Terdaftar Di Bursa Efek Indonesia Periode 2010-2013). Jurnal Online Mahasiswa (JOM) Bidang Ilmu Ekonomi, 6(2):201-120.

www.idx.co.id. Annual Financial Statement. diakses tanggal 20 April 2018.

Zu'amah. Ketetapan Klasifikasi Model Prediksi Kepailitan Akrual dan Bersbasis Aliran Kas. SNA VII,441459 